\title{
Research on the Determinants of China's Corporate Bond Credit Spreads
}

\author{
Li Heyi, Bei Zhengxin \\ PhD candidate, Professor \\ School of Business, Soochow University \\ Soochow, China \\ liheyi0731@gmail.com
}

\author{
George Chao Ma \\ Undergraduate \\ Cornell University \\ Ithaca, NY 14850-2488, USA \\ gcm52@cornell.edu
}

\begin{abstract}
Based on Merton structural model of corporate bond credit spreads, this paper estimates the China's expected credit spreads from credit risk measurement perspective. The structural model underestimates the predicted result shows that corporate bond credit spreads. Through the dynamic empirical analysis, we find that there still exists a close correlation between corporate credit spreads and output/inflation indicators when the credit risk was eliminated. It shows positive association with bond supply and stock volatility will generate negative spillover effects on corporate bond market. Bond maturity and the company's operating leverage show significant positive correlation to the difference between actual and estimated credit spread while the credit rating exhibits a negative correlation.
\end{abstract} Option

Keywords-Credit Spread, Structural Model, European Put

\section{INTRODUCTION}

The discrepancy between a corporate bond's higher yield and a risk-free bond's lower yield with the same maturity is called credit spreads. Among these risk-free bonds, majority chooses to use government bonds as basis for credit spread. Under the assumption of perfect market, corporate bond's main risks are credit risk and corporate bond default probability. Following the advancements of credit risk pricing models, corporate bond's credit spread is continuously approaching the default probability. However, Collin Dufresne, Goldstein and Martin's (2001) research dictates, a company bond's realistic credit spread is far greater than the expected loss; between the two there exists a "wide gap", which is the "credit spread puzzle."

Faced with empirical tests' massive doubts, researchers proposed two explanations for the gap in credit spread; some researchers believe, the reason why the current theoretical spread is way narrower than the corporate bond interest rate is because of the current measurement of credit risk and inadequate sample selection. They believe credit risk pricing model has room for improvements. Merton, using Black-Scholes' mathematical option pricing model as foundation, formulated a structural model of credit spread theory and corporate bond default model. Black and Cox thinks that corporate bond default not only happens at the maturity date, risk is associated at any moment from issuance to maturity. Besides this, they also researched how the seniority and subordinate bond, security provisions, dividends and cash dividends restrictions affect bond risk pricing. Geske utilized compound options method to price coupon bonds and provided a subordinated debt-pricing model under the compound options assumption.
Longstaff\& Schwartz inherited Black \& Cox's assumption of defaulting time; however, they deemed that the default boundary randomly fluctuates and thus incorporated the interest rate movement into the formula, calculated under Vasicek single factor model of interest rate, to produce credit risk pricing.

Other researchers thought outside of the credit risk and proposed that besides the risk of default there exist other factors that affect credit spread. Elton and Driessen think that corporate bond's and government bond's tax differences could account for $34 \%-57 \%$ of the credit spread. Even more scholars think that liquidity premium is the second biggest contributor. Also, important economic information, changes in government regulations and market intervention will have a drastic affect on market interest rate, thus causing changes to the risk premium.

In retrospect, it is not hard to find that in the perspective of China's current credit risk evaluation, there are not many papers using structural model for its corporate bond credit spread. Also, there is a lacking amount of scholars researching on structural model pricing result and affects.

\section{MERTON'S CORPORATE BOND PRICING MODEL}

\section{A. Credit Spread Calculation Methods}

To use Merton's method, we must first simplify the company's capital structure model. Suppose a company can only finance through stock, $S_{t}$ and a zero-coupon debt, which has the current market value of $B_{t}$ and maturity date at time $\mathrm{T}$ of face amount $\mathrm{D}$. Thus, the company's initial asset value $V_{t}$ satisfies: $V_{t}=S_{t}+B_{t}$

From Merton(1974) model assumption, corporate asset $\mathrm{V}_{\mathrm{t}}$ follows the Geometric Brownian motion:

$$
\frac{\mathrm{dV}_{\mathrm{t}}}{\mathrm{V}_{\mathrm{t}}}=\mu \mathrm{dt}+\sigma \mathrm{dZ} \mathrm{Z}_{\mathrm{t}}
$$

In this equation, $\mu$ and $\sigma$ represents the company's mean rate of return on asset and asset's return volatility respectively. $\mathrm{dZ}_{\mathrm{t}}=\varepsilon \sqrt{\mathrm{dt}}$, with $\varepsilon$ having a mean value of 0 and variance of 1 under the standard normal distribution. Thus,

$$
\mathrm{V}_{\mathrm{T}}=\mathrm{V}_{\mathrm{t}} \exp \left\{\left(\mu-\frac{\sigma^{2}}{2}\right)(\mathrm{T}-\mathrm{t})+\sigma \sqrt{(\mathrm{T}-\mathrm{t}) \varepsilon}\right\}
$$

If at $\mathrm{T}$ the company's value of $\mathrm{V}_{\mathrm{T}}$ is smaller than $\mathrm{D}$, then the company defaults on its debt; bondholders have first claim on the asset, leaving stockholders with nothing. However, if at time $\mathrm{T}, \mathrm{V}_{\mathrm{T}}$ is greater than $\mathrm{D}$, the company's debt holders can be paid the full face amount D. In such 
conditions, credit value is the same as the company's value of European call option, with face amount D and maturity

then they can avoid the corporate bond's credit risk. We can look at $\mathrm{P}_{\mathrm{t}}$ as a European put option price at time $\mathrm{t}$, which would make bondholder at time t risk-free.

$$
B_{t}+P_{t}=D e^{-r(T-t)}
$$

From Black-Scholes option pricing model, we can find the European put option price:

$$
\mathrm{P}_{\mathrm{t}}=-\Phi\left(-\mathrm{d}_{1}\right) \mathrm{V}_{\mathrm{t}}+D \mathrm{e}^{-\mathrm{r}(\mathrm{T}-\mathrm{t})} \Phi\left(-\mathrm{d}_{2}\right)
$$

$\Phi(\cdot)$ is the cumulative normal distribution.

$$
\begin{gathered}
\mathrm{d}_{1}=\frac{\ln \left(\mathrm{V}_{\mathrm{t}} / D \mathrm{D}^{-\mathrm{r}(\mathrm{T}-\mathrm{t})}\right)+(\mathrm{T}-\mathrm{t}) / 2 \sigma^{2}}{\sigma \sqrt{(\mathrm{T}-\mathrm{t})}} \\
\mathrm{d}_{2}=\mathrm{d}_{1}-\sigma \sqrt{(\mathrm{T}-\mathrm{t})}
\end{gathered}
$$

$\mathrm{De}^{-\mathrm{rT}} / \mathrm{V}_{0}$ is the gearing ratio, representing the company's financial structure.

Therefore, the bondholder's European put option price is a function of the gearing ratio. From the zero coupon bond $\mathrm{B}_{\mathrm{t}}=\mathrm{De}^{-\mathrm{y}_{\mathrm{T}}(\mathrm{T}-\mathrm{t})}$ and $\mathrm{B}_{0}+\mathrm{P}_{0}=\mathrm{De}^{-\mathrm{rT}}$ we get:

$$
\mathrm{y}_{\mathrm{T}}=-\frac{\ln \left\{\left(\mathrm{De} \mathrm{e}^{-\mathrm{r}(\mathrm{T}-\mathrm{t})}-\mathrm{P}_{\mathrm{t}}\right) / \mathrm{D}\right\}}{\mathrm{T}-\mathrm{t}}
$$

Combining put option price $\mathrm{P}_{\mathrm{t}}$, we can derive the credit spread:

$$
\begin{gathered}
C S=\mathrm{y}_{\mathrm{T}}-\mathrm{r} \\
=-\frac{1}{(\mathrm{~T}-\mathrm{t})} \ln \left[\Phi\left(\mathrm{d}_{2}\right)+\frac{\mathrm{V}_{0}}{\mathrm{De}^{-\mathrm{r}(\mathrm{T}-\mathrm{t})}} \Phi\left(-\mathrm{d}_{1}\right)\right]
\end{gathered}
$$

From the above model, the cost of getting rid of credit risk is affected by the asset's return volatility $\sigma$ and the bond's remaining time T.At the same time, it is under the affect of the risk-free interest rate. The higher the $r$, the lower the costs of reducing credit risk, which leads to a lower risk premium.

Merton's model only allows default at the maturity date. Other structural models such as Longstaff\&Schwardz model, Leland \&Toft model, Briys\&Varenne, SaaRequesjo\&Santa-Clara model, take into consideration default before maturity date. Publicly traded companies issue $95 \%$ of China's corporate bonds; these companies utilize third party guarantee, pledge guarantee, and mortgage guarantee to enhance credit. Because of these, China's corporate bond's creditors such as banks and insurance companies have a higher threshold that must be met for investments. Also, almost all of China's corporate bonds use European put option. Thus, from the structural model point of view, the Merton model is more suitable for China's current corporate bond.

\section{B. Parameter Estimation Method}

\section{I). Initial Asset $V_{0}$ Estimation}

The company's initial asset $V_{0}$ is equal to the sum of the company's stock market value and bond market value. China's corporate bonds are mainly issued by publicly traded companies, making their equity value easily accessible. This paper uses stock price per share and book debt per to estimate the company's asset $\mathrm{V}_{0}: \mathrm{V}_{\mathrm{t}}=\mathrm{S}_{\mathrm{t}}+\mathrm{B}_{\mathrm{t}}$. II). The Asset's Return Volatilityo Estimation date of $\mathrm{T}$. If a creditor bought such European call option,

This paper uses KMV's method to estimate asset's return volatility. The company asset's return volatility is derived from the historical volatility of its stock $\sigma_{\mathrm{s}}$ and its gearing ratio. $\sigma=\sigma_{\mathrm{s}} \frac{\mathrm{s}_{\mathrm{t}}}{\mathrm{V}_{\mathrm{t}}} \sigma_{\mathrm{s}}$. This paper utilizes stock information of every quarter to calculate the company's stock volatility and find its variance. $\mu \mathrm{i}=\operatorname{lnSi} /(\mathrm{Si}-$ 1), $\mathrm{i}=0,1,2, \ldots, 10$. Si and $\mathrm{Si}-1$ are the closing stock price of each quarter.

\section{COPORATE BOND CREADIT SPREAD ESTIMATION}

\section{A. Sample Selection}

China's corporate bond issuance started in 2007. After five years of development, corporate bond experienced massive market expansion. However, compared to other varieties of bonds, whether through market trading or theoretical research, it still lags behind. This paper selects publicly traded companies from Shenzhen Stock Exchange and Shanghai Stock Exchange that have publicly traded corporate bonds prior to 2010. According to the method of Merton's structural pricing model, there is a total of 10 credit spread estimations from each quarter starting from January of 2010 to June of 2012 for each company. To ensure each tested statistics is accessible, all corporate bonds must be issued from publicly traded companies and must not contain embedded conversion options. There are 44 corporate bonds that satisfy the above restrictions: 26 from Shanghai Stock Exchange and 18 from Shenzhen Stock Exchange. This paper's study sample is taken from Wind Database and chinabond.com.cn.

\section{B. Credit Spread Estimation Outcome}

Based on Merton's corporate bond pricing model, this paper uses Black-Scholes option-pricing formula to derive the incurred loses to guard against credit risk and the European put option premium. It further aims to understand the implications of credit spread within credit bond prices.

It is not hard to discern that credit spread estimation based on the structural model is generally smaller than the actual credit spread of the same time period; table 1 shows the model's prediction error. Merton's model for corporate bond credit spread estimation is 93 basis points lower than actual data and the estimated spread explains less than $45 \%$ of credit spread. The structural model starts from the company's capital structure and proposes the reason for default is based on the deterioration of the company's value. Once a company's value is lower than the trigger point $\left(V_{t}<D\right)$, then the bond is assumed to be defaulted. Thus, structural model's description of credit risk is transformed to a description of the company's value. 
Table1: Prediction Error（BP)

\begin{tabular}{lcc}
\hline & Predicted Spread & Actual Spread \\
\hline Mean Value & 129.26 & 222.13 \\
Standard Deviation & 164.13 & 124.42 \\
Maximum Value & 1138.21 & 677.74 \\
Minimum Value & -156.65 & -82.91 \\
\hline \multicolumn{1}{c}{ Adj. $R^{2}$} & & \\
\hline
\end{tabular}

Merton's model is the foundation to structural model. However, because of its over simplistic assumptions, there exists some blatant problems. Firstly, the model only assumes the issuer can distribute stock and zero coupon bonds. In practice, a company's capital structure is much more complex; corporate bonds not only include coupon bonds but also have other special features written in the indenture. Secondly, risk-free interest rate is often changing; this interest rate has a direct impact on the company's value. Thirdly, Merton model has strict data requirements. If the issuing company is not a publicly traded company, the model is incapable of predicting the credit spread.

Many models are developed based on Merton's model in order to find answers to these problems above such as the
KMV and the Credit Grades model. However, due to the innate limitations of the structural models and the assumption that default is influenced by capital structure, there still exists a huge gap between the scholars' empirical results and actual spread. Faced with a large gap from the empirical and actual credit spread, many scholars made an effort to use factors other than default risk to explain the remaining difference. The main current views are tax differences, liquidity premium, market risk and interest rate. For further investigation of the determinants of corporate bond credit spread, we will first sort the prediction error into difference categories like the one below.

Table 2: Credit Spread Decomposition (BP)

\begin{tabular}{llcccc}
\hline Classification & & $\begin{array}{c}\text { Difference of actual and } \\
\text { estimated spread }\end{array}$ & $\begin{array}{c}\text { Biggest } \\
\text { Value }\end{array}$ & $\begin{array}{c}\text { Smallest } \\
\text { Value }\end{array}$ & $\begin{array}{c}\text { Standard } \\
\text { Deviation }\end{array}$ \\
\hline \multirow{6}{*}{ Credit Rating } & AAA & 96.13 & 323.00 & -222.82 & 106.22 \\
& AA+ & 159.59 & 468.28 & -280.33 & 133.30 \\
& AA & 226.14 & 488.49 & -120.83 & 118.14 \\
& AA- & 279.08 & 319.00 & -261.00 & 110.34 \\
\hline \multirow{2}{*}{ Exchange Market } & Shenzhen & 125.26 & 644.25 & -287.63 & 295.31 \\
& Shanghai & 68.87 & 529.39 & -698.22 & 214.57 \\
\hline \multirow{3}{*}{ Maturity } & 0-3years & 168.69 & 425.59 & -210.37 & 124.16 \\
& 3-5years & 173.48 & 488.49 & -280.33 & 136.11 \\
& Over5years & 192.19 & 468.28 & -114.81 & 107.76 \\
\hline
\end{tabular}

From the results of table 2, a company's credit rating and the accuracy of the model have a negative correlation: the higher the credit rating, the closer the structural model's estimation to the actual credit spread. From the classification of different exchange markets, the difference between actual and estimated spread differ by 50 basis points. This phenomenon may be accounted for by the difference in the issuer's scale of operation and the bond's issuing scale. Company that issue corporate bonds in Shenzhen Exchange Market are mainly medium to small companies; thus the risk associated with these companies are higher than those exchanging in Shanghai Exchange Market. Corporate bond's maturity date also has a positive correlation with the difference of actual and estimated spread, the longer the maturity date the greater the difference. From the above analysis, it is clear a company's credit rating and maturity date have an impact on the accuracy of the model. This paper has a fourth part, which looks at the macro, the corporate and the issuer level and their regression analyses.

\section{DYNAMIC ANALYSIS OF DETERMINANTS OF THE PRICING ERROR}

The bond market analysis is based on the direction and the shape of the yield curve. In practice, many investors also judge the macro effect of the corporate bond market and the investment environment to further analyze the trend in the bond market.

This paper, based on panel data's regression model, studies the influences of corporate bond spreads on the macro, corporate and issuer level. These influences include factors such as the corporate bond's duration, company's turnover rate, credit rating, ROE ratio, etc. Because this paper places a heavy emphasis upon the change in credit spread in adjacent time periods, macro indicators will have a different treatment. 
Table 3 Determinants of the Structural Model Pricing Error

\begin{tabular}{|c|c|c|c|}
\hline Variable & & Interpretation of Indicator & Expected Effect \\
\hline \multirow{5}{*}{ Macro Level } & $C P I$ & Last quarter's CPI value as price index & - \\
\hline & $P M I$ & Last quarter's PMI values as output indicators & - \\
\hline & $V I X$ & Shanghai and Shenzhen 300 index 60 day volatility & - \\
\hline & Yield & 10 year government treasury yield & - \\
\hline & Bsupply & Last quarter's bond issuance as bond supply index & + \\
\hline \multirow{3}{*}{ Corporate Level } & Duration & Corporate Debt Maturity Date & + \\
\hline & Turnover & Corporate Debt Monthly Turnover Rate & - \\
\hline & Rating & Corporate Bond Credit Rating & - \\
\hline \multirow{3}{*}{ Issuer Level } & $\operatorname{Lvg}$ & Uses the issuing company's debt to asset ratio & + \\
\hline & $R O E$ & Return on Equity & + \\
\hline & Illiquidity & Uses Amihud(2002) method to calculate illiquidity & - \\
\hline
\end{tabular}

Among them, there is no one universal and accurate measurement for a company's bond liquidity. Taking into consideration the accessibility of the data, this paper uses low frequency transactional data based on Amihud (2002) method. It uses the absolute return per dollar of bond exchanged to calculate corporate bond's liquidity:

$$
\text { illiquidity }=\frac{1}{\mathrm{D}} \sum_{\mathrm{i}=1}^{\mathrm{D}} \frac{\mathrm{r}_{\mathrm{it}}}{\mathrm{vol}_{\mathrm{it}}}
$$

Table 4 Panel Data Regression Result

\begin{tabular}{|c|c|c|c|}
\hline Indicator & Model 1 & Model 2 & Model 3 \\
\hline$C$ & $\begin{array}{l}1.132542 \\
(0.823562)\end{array}$ & $\begin{array}{l}1.01329 \\
(0.9123256)\end{array}$ & $\begin{array}{l}0.92632 \\
(0.625263)\end{array}$ \\
\hline$\Delta C P I$ & $\begin{array}{l}-0.0245^{*} \\
(2.152634)\end{array}$ & $\begin{array}{l}-0.0341^{*} \\
(2.312325)\end{array}$ & $\begin{array}{l}-0.0323^{*} \\
(2.221452)\end{array}$ \\
\hline$\triangle P M I$ & $\begin{array}{l}-0.0312 * * \\
(3.285363)\end{array}$ & $\begin{array}{l}-0.0326 * * \\
(3.795126)\end{array}$ & $\begin{array}{l}-0.0213 * * \\
(3.842231)\end{array}$ \\
\hline$\Delta V I X$ & $\begin{array}{l}-0.0233 * * \\
(-2.8956623)\end{array}$ & $\begin{array}{l}-0.0256^{* *} \\
(-2.633261)\end{array}$ & $\begin{array}{l}-0.0214 * * \\
(-2.536231)\end{array}$ \\
\hline$\Delta$ Yield & $\begin{array}{l}-0.5932 * \\
(1.654823)\end{array}$ & $\begin{array}{l}-0.4801 * \\
(1.623562)\end{array}$ & $\begin{array}{l}-0.4626 \\
(1.178256)\end{array}$ \\
\hline$\Delta$ Bsupply & $\begin{array}{l}0.0205 * * \\
(2.651622)\end{array}$ & $\begin{array}{l}0.0198 * * \\
(2.231206)\end{array}$ & $\begin{array}{l}0.0213 * * \\
(2.0311452)\end{array}$ \\
\hline Duration & & $\begin{array}{l}0.1223^{*} \\
(2.112526)\end{array}$ & $\begin{array}{l}0.1521 * * \\
(2.825212)\end{array}$ \\
\hline Turnover & & $\begin{array}{l}-0.1232 \\
(0.7626312)\end{array}$ & $\begin{array}{l}-0.2695 \\
(0.6215257)\end{array}$ \\
\hline Rate & & $\begin{array}{l}-0.6253 * * * \\
(-3.892451)\end{array}$ & $\begin{array}{l}-0.5489 * * * \\
(-4.165235)\end{array}$ \\
\hline$L v g$ & & & $\begin{array}{l}0.4895 * * * \\
(6.9425131)\end{array}$ \\
\hline$R O E$ & & & $\begin{array}{l}0.1256 \\
(0.1533256)\end{array}$ \\
\hline Illiquidity & & & $\begin{array}{l}0.1352 \\
(0.6952262)\end{array}$ \\
\hline Adj. $R^{2}$ & 0.192546 & 0.224631 & 0.342506 \\
\hline
\end{tabular}

where $r_{i t}$ is the bond price amplitude at time $t, v l_{i t}$ as the exchange days at time $t$. The intuitive meaning behind this liquidity measurement method is that if there is a huge difference in bond trading prices, the bond's liquidity will lessen due to greater bond price amplitude. total transactional amount at time $t$, and $\mathrm{D}$ as the number of 
Note: This paper uses the difference between actual and estimated credit spread calculated previously. $* * *, * *$, and $*$ represent $1 \%, 5 \%$ and $10 \%$ level of significance respectively.

Model 1 only takes into consideration the macro effects. The explanatory and explained variables are difference of the first order. The regression model assumes that it's the default fixed-effects model; thus Hausman test is not needed. In table 4, PMI and CPI show a strong negative correlation with the difference in estimated and actual credit spread. This implies that the higher the inflation/output value, the closer and more accurate the estimated model is to the actual spread. In the above table, the 10-year government treasury yield also exhibits a negative correlation with difference in the two credit spreads at the $10 \%$ significance level. The actual corporate bond credit spread is calculated by the difference between the bond yield and basic yield. This form of calculation contains certain time difference errors. Thus, CPI and PMI's influence on the basic yield has a corresponding effect on corporate bond credit spread.

From model 2's regression result, the duration of the corporate bond and credit rating have a strong correlation with the difference in spread. The regression model shows that credit rating has a negative correlation with the difference; this is the same as our expected results. This proves that the greater the corporate bond's credit rating, the smaller the difference in spread and thus greater accuracy of the structural model. The opposite is true for duration as it has a positive correlation with the difference.

Model 3 shows that a company's capital structure and its bond's credit spread have an extremely strong correlation. This validates the strong basis for basing the structural model upon the company's capital structure. However, the company's stock volatility and the credit spread difference have a negative correlation. This shows that as the stock volatility of publicly traded company increases, the model's error becomes smaller. This can be understood as the risk premium to compensate for the credit risk within the corporate bond is larger. The Shanghai and Shenzhen 300 index's regression result also accounts for the "flight-to-quality" phenomenon between stock and bond investment.

The company's illiquidity has no correlation with the difference in credit spread. However, considering the low liquidity of China's corporate bonds, investors investing in corporate bonds inevitably already take into consideration the compensation for the low liquidity. In this study, the empirical regression coefficient is not significant. For future test, if data is accessible, it can use high frequency transaction data based on the sale price method to measure liquidity.

\section{CONCLUSION}

Based on Merton's corporate bond pricing model, this paper conducted empirical prediction on China's corporate bond credit spread from a credit risk perspective. From the model's prediction results, it is clear that the structural model is significant lower than the actual corporate bond credit spread; there exists a "wide gap" between the estimated and actual credit spread.

Based on this foundation, this paper used panel data to perform regression analysis on the determinants of this gap. This way, by already taking account of the credit risk, we can further analyze whether macro, corporate or issuer level factors influence credit spread. After empirical research, we found that CPI, PMI, VIX and credit rating have a negative correlation with this gap; the greater these indicators are, the lesser the gap. The study also shows that the corporate bond's duration, leverage and overall bond supply have a positive correlation with the gap. From a theoretical point of view, a corporate bond's liquidity is a huge influencing factor of credit spread. However, this paper's empirical study shows that this is not the case. This may be the result of method of calculation for liquidity and the accessibility of data.

\section{REFERENCES}

[1] Altman, E. and V. kishore,1996, "Almost Everything You Wanted to Know About Recoveries on Defaulted Bonds", Financial Analysts Journal, Vol.52, No.6, Nov. pp.57-64

[2] Anderson, R. W. and S. M. Sundaresan, 2000, "A Comparative Study of Structural Models of Corporate Bond Yields: An Exploratory Investigation", Journal of Banking \& Finance, Vol.24, No.1, Jan., pp.255269.

[3] Black, Fand J. Cox, 1976, "Valuing Corporate Securities: Some Effects of Bond Indenture Provisions", Journal of Finance, Vol. 31, No.2. May. pp.351-367.

[4] Duan. J. 1994, "Maximum likelihood estimation using price data of the derivative contract”, Mathematical Finance,Vol.4.No.2, Apr. pp.155-167.

[5] Giesecke, K.2001, "Default and Information", working paper, Cornell University. 